\title{
The Mechanism of Foreign Strategic Investment Affecting Efficiency of Chinese Banks
}

\author{
Yuhua $\mathrm{Li}^{1,2}$, Tongsheng $\mathrm{Xu}^{1} \&$ Honglin Yuan ${ }^{1}$ \\ ${ }^{1}$ School of International Trade and Economics, Jiangxi University of Finance and Economics, Nanchang, China \\ ${ }^{2}$ Jiahede-Jiangxi University of Finance and Economics Postdoctoral Innovation Practical Base, China \\ Correspondence: Yuhua Li, School of International Trade and Economics, Jiangxi University of Finance and \\ Economics, 330013, Nanchang, China. Tel: 86-791-83816581. E-mail: yuhuali28@gmail.com
}

Received: October 11, 2014

doi:10.5539/ijef.v6n12p212
Online Published: November 25, 2014

URL: http://dx.doi.org/10.5539/ijef.v6n12p212

\begin{abstract}
Foreign financial institutions' strategic investment in China's banking sector is to acquire certain equity stake of Chinese banks and provide business assistance and cooperation to them, and it is one of the important foreign bank entry modes in China. This paper explores the impacting mechanism of foreign strategic investment on efficiency of different types of Chinese banks. Foreign strategic investments have several characterisitics: foreign equity ownership should be less than $20 \%$ for one strategic investor; foreign financial institutions could send foreign directors to Chinese bank board; they must provide business cooperation with Chinese banks; their equity share must be locked up at least in 3 years. We propose that foreign financial institutions have more incentive to improve the efficiency of smaller Chinese banks which include city commercial banks, rural commercial banks, and most joint-owned commercial banks; foreign directors also have more incentive to improve the corporate governance of smaller Chinese banks; foreign financial institutions would likely to transfer more technology to smaller Chinese banks than that to big Chinese banks, which mainly are the state-owned commercial banks. The longer holding periods of Chinese banks equity also make foreign financial institutions have more incentive to improve the efficiency of Chinese banks. In addition, the interest conflict between state-owned commercial banks and their foreign investors is larger than that between smaller Chinese banks and their foreign investors.
\end{abstract}

Keywords: foreign strategic investment, Chinese banks, business cooperation, efficiency, mechanism

\section{Introduction}

Starting from the 1990s, foreign financial institutions have been expanding their presence in emerging countries of Central and Eastern Europe, Latin America, and Asia, and foreign ownership in the banking sector has increased sharply. Foreign bank entry in Central and Eastern European countries has led to foreign ownership in the local banking system often in excess of $80 \%$ of local banking system assets (Goldberg, 2007). The proportion of foreign-owned banks remains relatively low in Asia, but it has increased dramatically after the Asian Financial Crisis (Montgomery, 2003). Foreign ownership is especially sensitive in emerging countries since many immature financial systems in these countries rely heavily on banks to channel financial resources to development priorities (Zhu, 2007). In terms of foreign bank entry mode, exist studies on foreign bank entry mostly focus on wholly-owned subsidiary and branch, as far as I know, few of previous studies focus on strategic investment. In China, before December 2006, many foreign financial institutions enter Chinese banking sector in the form of strategic investment into Chinese banks.

Several previous studies examine the impact of foreign strategic investment on Chinese banks. Laurenceson\& Qin (2008) used 65 Chinese banks over 2001-2006 to examine the impact of foreign minority investment on cost efficiency, and the result was positive but insignificantly. García-HerreroandSantabárbara (2008) examine 82 Chinese banks over 1999-2006 and found that the Chinese banking sector has benefited from foreign investment through higher profitability and increased efficiency of the banking system. Moreover, Berger et al. (2009) analyzed the efficiency of 38 Chinese banksover 1994-2003, and found that minority foreign ownership is associated with significantly improved efficiency and minority foreign ownership of the Big Four will likely improve performance significantly.However, Shen et al. (2009) examined 48 Chinese banks over 1997-2007 and used the percentage shareholding of foreign strategic investors in a Chinese bank as independent variables and 
found that it affects neither profitability nor costs.Yuan andGunji(2009) used panel data on 19 major Chinese banks during 1996-2004 to examine the impact of foreign capital participation and found that the net effect of the foreign investment on the profitability of domestic banks is small.

These studies have inconsistent results, García-Herrero and Santabárbara (2008) and Berger et al. (2009) found positive and significant impact of foreign bank entry. Shen et al. (2009), Laurenceson and Qin (2008), and Yuan and Gunji (2009) found no impact or small impact of the foreign entry. One main reason for the inconsistent results is that they don't consider the variety of Chinese banks which is strategically invested by foreign financial institutions. There are four types of Chinese banks, state-owned commercial banks (SOCBs), joint-owned commercial banks(JOCBs), city commercial banks (CCBs), and rural commercial banks (RCBs). The difference on ownership structure, network distribution, customer, market size, and other sides among different types of Chinese banks are very big. These varieties of Chinese banks may contribute to the inconsistent results on the impact of foreign strategic investment on efficiency of different types of Chinese banks.

The reminders of the paper are as follows. Section 2 presents background information on foreign strategic investment in Chinese banks. Frameworks and the propositions about the impact of foreign strategic investment in Chinese banks are developed in section 3. Section 4 concludes.

\section{Background Information}

The Chinese banking sector is the most important component of the financial system but it still remains undercapitalized, low efficiency, and saddled with non-performing loans before 2001(García-Herrero et al., 2009; Hawes \& Chiu, 2006; Hope \& Hu, 2006; Tan, 2009). The Asian Financial Crisis in 1997 made Chinese banking regulators aware of the vulnerability of China's banking system. In addition, the accession into the World Trade Organization required China to open its banking industry by the end of 2006 so that Chinese banks are forced to face competition with foreign financial institutions (Bonin \& Huang, 2002). As a result, the Chinese authorities have sought to attract foreign strategic investments to help restructure and modernize the ailing Chinese banks.

Foreign equity investments in Chinese banks were allowed in 2001 with some restrictions; foreign investors needed to receive approval from the People's Bank of China, which is the central bank in China; percentage ownership by a single investor was not allowed to exceed $15 \%$ (total percentage ownership by all foreigners was allowed up to $20 \%$ ). The China Banking Regulatory Commission promulgated the Regulations on Equity Investment of Foreign Financial Institutions in Chinese Financial Intuitions on December 8, 2003 that increased the upper limit on percentage ownership of a single foreign investor from $15 \%$ to $20 \%$. The limitation of total foreigners' percentage ownership was simultaneously increased to $25 \%$. As a result of these deregulations and encouragement, foreign financial institutions undertake strategic investments in national joint-stock banks and even in the state-owned banks, as well as in city commercial banks.In China, there are 26 Chinese banks, which introduced foreign strategic investment from foreign financial institutions during 2001-2008. It includes 4 state-owned commercial banks, 9 joint-stock commercial banks, 11 city commercial banks, and 2 rural commercial banks.

In China's banking sector, the strategic investments have 5 characteristics. First,foreign financial institutions are required in strategic investments to own at least 5\% share of the domestic bank. Second,foreign strategic investors are also obliged to set a lock-up period, at least in 3 years. Third, foreign financial institutions have the right to nominate foreign directors to the board. Chinese banking regulators also hope foreign directors could improve domestic banks' corporate governance. Fourth, Chinese banking regulations require foreign investors to cooperate with or assist Chinese banks on some businesses and with their management system. These fields are information technology, internal control and human resource management, and cooperation in retail, corporate, and private banking businesses. These strategic investors are internationally reputable banks (for example, Citigroup, Goldman Sachs, UBS, Royal Scotland Bank, HSBC, Temasek), which have substantial experience and expertise. Fifth, foreign commercial banks invest less than 2 Chinese banks in principle.

\section{Theoretical Framework and Impacting Mechanism}

Through analyzing the characteristics of foreign strategic investments in China's banking sector, we employ the equity incentive theory, corporate governance, technology transfer, interest conflict and other factors to examine the impact mechanism of foreign strategic investment on efficiency of Chinese banks, see Figure 1 theorectical framework on the impacting mechanism. As we know, the difference on ownership structure, network distribution, customers, market size, and other sides, among different types of Chinese banks are very big, so we would likely to know the differences of foreign strategic investment on different types of Chinese banks.Specifically, we try to find out the differences on the impact of foreign equity ownership, foreign directors, 
business cooperation, lock-up peropds, and interest conflict on efficiency of SOCBs, JOCBs, CCBs, and RCBs.

We hand-collected information on foreign strategic investments from media and banks' annual reports, the RESSET database, the Bankscope database, and previous studies (García-Herrero \& Santabárbara, 2008; Li, 2013, 2014; Li \& Yue, 2014; Li \& Uchida, 2011; Zhu et al., 2008). The information includes percentage equity stake, business cooperation, foreign directors, lock-up periods, agreement date, and so on.

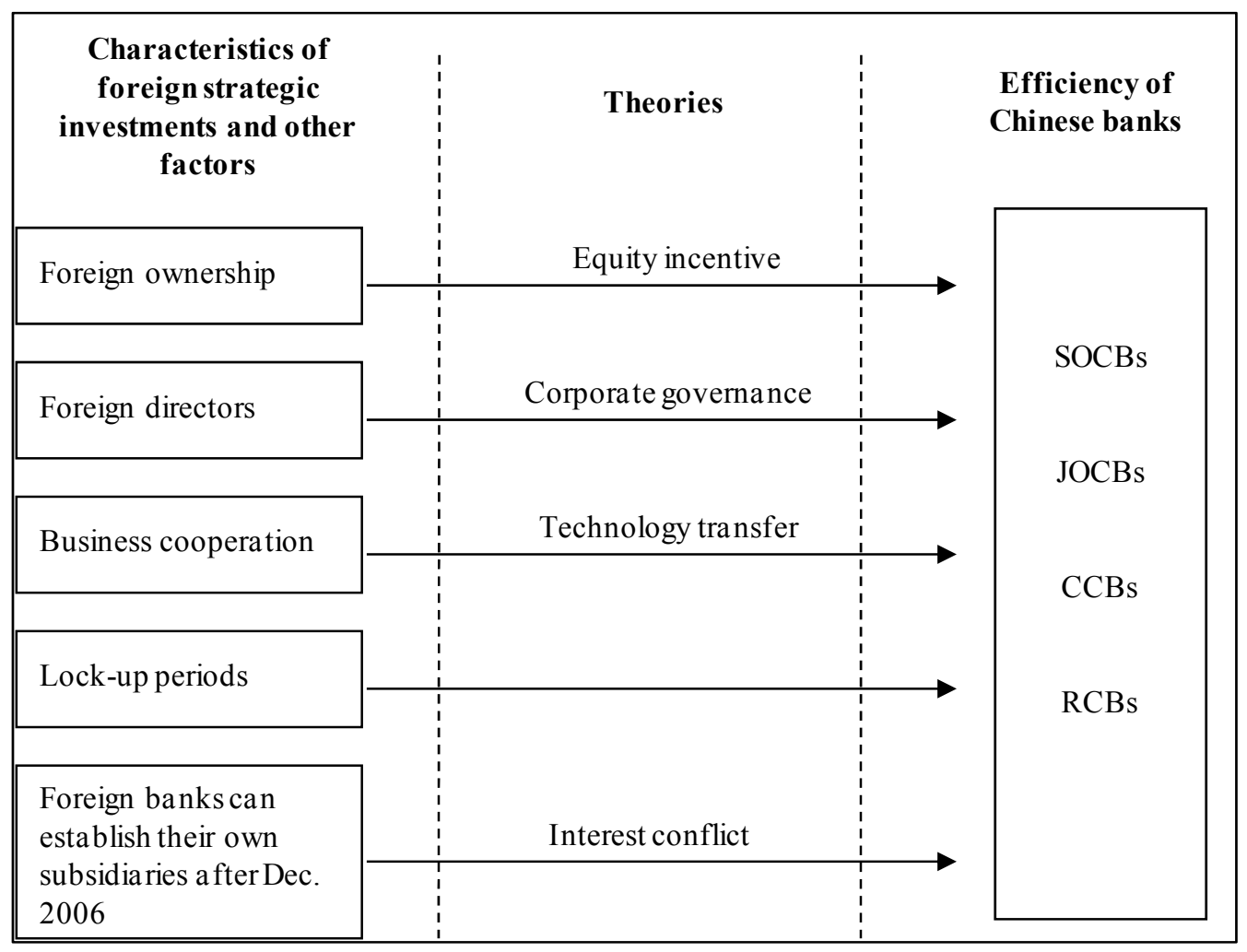

Figure 1. Theoretical framework on impact mechanism

Certain equity ownership of foreign financial institutions in Chinese banks implies that foreign strategic investors have the incentive to make some big decisions in the shareholder meetings which would improve efficiency of Chinese banks. However, some foreign financial institutions maintain low equity stakes (less than $10 \%$ ), which means that foreign investors cannot retain strong control power. Different levels of foreign shareholdings provide different levels of incentives for foreign strategic investors to improve efficiency of Chinese banks. Majority equity ownership would engender positive effect on efficiency of Chinese banks; however, the minority equity ownership could not engender positive effect. As Table 1 shows, the foreign equity ownership in most SOCBs is relatively lower than that in most CCBs and RCBs. Foreign equity ownership in 9 CCBs (the total CCBs number is 11) is larger than $10 \%$ and foreign equity ownership in both RCBs are larger than $10 \%$. For example, the first biggest shareholder of China Bohai Bank is its foreign strategic investor, Standard Charted Bank. However, foreign equity ownership in 3 SOCBs (the total SOCBs number is 4) is smaller than $10 \%$. That would be one reason why three of four SOCBs (Bank of China, Industrial and Commercial Bank of China, and China Construction Bank) experience divestment from their foreign strategic investors. Therefore, we get one proposition as follows:

Proposition 1: More foreign equity ownership in Chinese banks, foreign financial institutions intends to have more incentive to improve the efficiency of CCBs, RCBs, and most JOCBs than that of SOCBs. 
Table 1. Foreign strategic investment in China's banking sector

\begin{tabular}{|c|c|c|c|c|c|c|c|}
\hline $\begin{array}{l}\text { Chinese } \\
\text { bank } \\
\text { type }\end{array}$ & Chinese bank & $\begin{array}{l}\text { Foreign bank } \\
\text { (Symbol) }\end{array}$ & $\begin{array}{l}\text { Agreement } \\
\text { date }\end{array}$ & $\begin{array}{l}>10 \% \\
(Y \text { or } N)\end{array}$ & $\begin{array}{l}\text { Foreign } \\
\text { directors }\end{array}$ & $\begin{array}{l}\text { Lock-up period } \\
\text { (years) }\end{array}$ & $\begin{array}{l}\text { Divestment (Y } \\
\text { or N) untill } \\
2012.12 .31\end{array}$ \\
\hline SOCB & $\begin{array}{l}\text { Bank of } \\
\text { Communications }\end{array}$ & HSBC & $2004 / 8 / 6$ & $\mathrm{Y}$ & 2 & NA & $\mathrm{N}$ \\
\hline SOCB & $\begin{array}{l}\text { China Construction } \\
\text { Bank }\end{array}$ & $\begin{array}{l}\text { Bank of America } \\
\text { Temasek Holdings } \\
(\mathrm{TH})\end{array}$ & $\begin{array}{l}2005 / 6 / 17 \\
2005 / 7 / 1\end{array}$ & $\begin{array}{l}\mathrm{N} \\
\mathrm{N}\end{array}$ & $\begin{array}{l}1 \\
1\end{array}$ & $\begin{array}{l}3 \text { years after IPO } \\
\text { NA }\end{array}$ & $\begin{array}{l}\mathrm{Y} \\
\mathrm{Y}\end{array}$ \\
\hline SOCB & Bank of China & $\begin{array}{l}\text { UBS } \\
\text { RBS } \\
\text { coinvestors }^{\text {a) }}\end{array}$ & $\begin{array}{l}2005 / 9 / 27 \\
2005 / 8 / 18\end{array}$ & $\begin{array}{l}\mathrm{N} \\
\mathrm{N}\end{array}$ & $\begin{array}{l}1 \\
1\end{array}$ & $\begin{array}{l}3 \\
3\end{array}$ & $\begin{array}{l}\mathrm{Y} \\
\mathrm{Y}\end{array}$ \\
\hline & & $\mathrm{TH}$ & $2005 / 8 / 31$ & $\mathrm{Y}$ & 1 & 3 & $\mathrm{Y}$ \\
\hline SOCB & $\begin{array}{l}\text { Industrial \& } \\
\text { Commercial Bank of } \\
\text { China }\end{array}$ & $\begin{array}{l}\text { Goldman Sachs } \\
\text { Allianz } \\
\text { American Express }\end{array}$ & $\begin{array}{l}2006 / 1 / 27 \\
2006 / 1 / 27 \\
2006 / 1 / 27\end{array}$ & $\begin{array}{l}\mathrm{N} \\
\mathrm{N} \\
\mathrm{N}\end{array}$ & $\begin{array}{l}1 \\
0 \\
0\end{array}$ & $\begin{array}{l}3 \\
3 \\
3\end{array}$ & $\begin{array}{l}\mathrm{Y} \\
\mathrm{Y} \\
\mathrm{Y}\end{array}$ \\
\hline JOCB & $\begin{array}{l}\text { Shanghai Pudong } \\
\text { Development Bank }\end{array}$ & Citigroup & $2003 / 1 / 1$ & $\mathrm{~N}$ & 1 & 5 & $\mathrm{~N}$ \\
\hline $\mathrm{JOCB}$ & $\begin{array}{l}\text { China Industrial } \\
\text { Bank }\end{array}$ & Hang Seng Bank & $2003 / 12 / 17$ & $\mathrm{Y}$ & 1 & NA & $\mathrm{N}$ \\
\hline $\mathrm{JOCB}$ & $\begin{array}{l}\text { Shenzhen } \\
\text { Development Bank }\end{array}$ & Newbridge Asia & $2004 / 5 / 29$ & $\mathrm{Y}$ & NA & 5 & $\mathrm{Y}$ \\
\hline JOCB & $\begin{array}{l}\text { China Mingseng } \\
\text { Bank }\end{array}$ & $\mathrm{TH}$ & $2004 / 10 / 16$ & $\mathrm{~N}$ & 1 & 2 years & $\mathrm{Y}$ \\
\hline JOCB & China Bohai Bank & Standard Chartered & $2005 / 09 / 06$ & $\mathrm{Y}$ & 2 & NA & $\mathrm{N}$ \\
\hline JOCB & Huaxia Bank & $\begin{array}{l}\text { Deutsche Bank } \\
\text { Sal Oppenheim }\end{array}$ & $\begin{array}{l}2005 / 10 / 17 \\
2005 / 10 / 17\end{array}$ & $\begin{array}{l}\mathrm{Y} \\
\mathrm{N}\end{array}$ & $\begin{array}{l}1 \\
0\end{array}$ & $\begin{array}{l}5 \\
5\end{array}$ & $\begin{array}{l}\mathrm{N} \\
\mathrm{N}\end{array}$ \\
\hline JOCB & China CITIC Bank & $\begin{array}{l}\text { Banco Bilbao } \\
\text { Vizcaya Argentaria }\end{array}$ & $2006 / 11 / 22$ & $\mathrm{~N}$ & 2 & 3 & $\mathrm{~N}$ \\
\hline JOCB & $\begin{array}{l}\text { Guangdong } \\
\text { Development Bank }\end{array}$ & Citigroup & $2006 / 11 / 16$ & $\mathrm{Y}$ & 3 & 6 & $\mathrm{~N}$ \\
\hline JOCB & Evergrowing Bank & $\begin{array}{l}\text { United Overseas } \\
\text { Bank }\end{array}$ & $2008 / 6 / 26$ & $\mathrm{Y}$ & 1 & NA & $\mathrm{N}$ \\
\hline $\mathrm{CCB}$ & Bank of Shanghai & HSBC & $2001 / 12 / 29$ & $\mathrm{~N}$ & 1 & $\mathrm{NA}$ & $\mathrm{N}$ \\
\hline $\mathrm{CCB}$ & $\begin{array}{l}\text { Xian City } \\
\text { Commercial Bank }\end{array}$ & $\begin{array}{l}\text { Bank of Nova } \\
\text { Scotia }\end{array}$ & $2003 / 06 / 27$ & $\mathrm{Y}$ & 1 & NA & $\mathrm{N}$ \\
\hline $\mathrm{CCB}$ & Qilu Bank & $\begin{array}{l}\text { Commonwealth } \\
\text { Bank of Australia }\end{array}$ & $2004 / 09 / 08$ & $\mathrm{Y}$ & 1 & NA & $\mathrm{N}$ \\
\hline $\mathrm{CCB}$ & Bank of Beijing & ING & $2005 / 3 / 25$ & $\mathrm{Y}$ & 2 & NA & $\mathrm{N}$ \\
\hline $\mathrm{CCB}$ & Bank of Hangzhou & $\begin{array}{l}\text { Commonwealth } \\
\text { Bank of Australia }\end{array}$ & $2005 / 04 / 21$ & $\mathrm{Y}$ & 1 & NA & $\mathrm{N}$ \\
\hline $\mathrm{CCB}$ & $\begin{array}{l}\text { Nanchong } \\
\text { Commercial Bank }\end{array}$ & DEG & $2005 / 07 / 08$ & $\mathrm{Y}$ & 2 & NA & $\mathrm{N}$ \\
\hline $\mathrm{CCB}$ & Bank of Nanjing & BNP Paribas & $2005 / 10 / 12$ & $\mathrm{Y}$ & 1 & NA & $\mathrm{N}$ \\
\hline $\mathrm{CCB}$ & Bank of Tianjin & $\begin{array}{l}\text { ANZ Banking } \\
\text { Group (ANZ) }\end{array}$ & $2005 / 12 / 06$ & $\mathrm{Y}$ & 2 & NA & $\mathrm{N}$ \\
\hline $\mathrm{CCB}$ & Bank of Ningbo & OCBC Bank & $2006 / 1 / 10$ & $\mathrm{Y}$ & 2 & 10 & $\mathrm{~N}$ \\
\hline $\mathrm{CCB}$ & Bank of Chongqing & Dah Sing Bank & $2006 / 12 / 21$ & $\mathrm{Y}$ & 2 & NA & $\mathrm{N}$ \\
\hline $\mathrm{CCB}$ & $\begin{array}{l}\text { Bank of Qingdao Co } \\
\text { Ltd }\end{array}$ & Intesa Sanpaolo & $2007 / 07 / 12$ & $\mathrm{Y}$ & 2 & NA & $\mathrm{N}$ \\
\hline $\mathrm{RCB}$ & $\begin{array}{l}\text { Hangzhou United } \\
\text { Rural Cooperative } \\
\text { Bank }\end{array}$ & Rabobank & $2005 / 10 / 17$ & $\mathrm{Y}$ & 2 & NA & $\mathrm{N}$ \\
\hline $\mathrm{RCB}$ & $\begin{array}{l}\text { Shanghai Rural } \\
\text { Commercial Bank }\end{array}$ & ANZ & $2006 / 11 / 21$ & $\mathrm{Y}$ & 2 & NA & $\mathrm{N}$ \\
\hline
\end{tabular}

Source: Compiled by authors according to the media, banks' annual reports, RESSET database, Zhu et al. (2008), and García-Herrero and 


\section{Santabárbara (2008)}

Note. When a single bank receives foreign strategic investments several times, this study adopts only the first introduction foreign strategic investments.

a) The coinvestors include Li Ka-Sing Foundation, Merry Lynch, and RBS, which invested 1600 million for about 5.2 percentage equity stakes. NA: not available.

SOCBs: state-owned commercial banks; JOCBs: joint-stock owned commercial banks; CCBs: city commercial banks; RCBs: rural commercial banks.

Foreign financial institutions have certain equity stakes in Chinese banks, so they have the right to nominate the foreign directors to Chinese banks' board. The directors sent by foreign financial institutions would urge Chinese banks to establish reasonable and appropriate corporate governance mechanism and then improve the role of the board on Chinese banks' operations and management. With respect to foreign financial institutions' equity ownership, they would send corresponding number of directors to Chinese banks' board. Foreign financial institutions have large equity stake in $\mathrm{CCBs}$, RCBs and most JOCBs than that of SOCBs, so they have the right to nominate more foreign directors to $\mathrm{CCBs}$, RCBs and most JOCBs. More directors would give more pressure to Chinese banks to improve their own corporate governance level. In addition, more foreign equity ownership usually means more incentive to improve the corporate governance and management of CCBs, RCBs and most JOCBs.

Proposition 2: More directors sent by foreign financial institutions into Chinese banks, and more incentive they have to improve the corporate governance of CCBs and RCBs than that of SOCBs.

Foreign financial institutions have business assistance and cooperation on retail banking, corporate banking, private banking, credit card, information technology, internal control, risk management, and human resource management. Since these strategic investors are internationally reputable banks (for example, Citigroup, Goldman Sachs, UBS, Royal Scotland Bank, HSBC, Temasek), they have substantial expertise and technologies on these areas. Foreign financial institutions have much higher incentives for technology transfer if they hold large equity shares of Chinese banks. However, low equity stake potentially provides insufficient incentives to transfer technologies to Chinese banks, because foreign investors can receive only a small part of the increased value (Laurenceson \& Qin, 2008). Foreign financial institutions have large equity stake in CCBs, RCBs and most JOCBs than that of SOCBs, so they have more incentive to transfer technologies to CCBs, RCBs and most JOCBs.

Proposition 3: Foreign financial institutions are likely to transfer more technologies to CCBs, RCBs and most JOCBS than that to SOCBS.

The settlement of the lock-up periods on foreign equity shares means the strategic commitment of foreign financial institutions in Chinese banks. The longer of the lock-up periods, the great strategic commitment of foreign financial institutions made to Chinese banks. Since the lock-up periods of many foreign strategic investments are not open, we collect the divestment information conducted by foreign strategic investors during the intial investement day until December 2012, as Table 1 shows. The periods of foreign financial institutions holding Chinese banks equity can also show the strategic commitment of foreign financial institutions. The longer holding periods, foreign financial institutions have more incentive to improve efficiency of Chinese banks. From analyzing lock-up periods, we find that three of four SOCBs have 3 years lock-up periods. If Chinese banks do not experience divestment, it means that their foreign strategic investors have the stronger and longer incentive to improve efficiency of Chinese banks. As we can see from Table 1, until December 31, 2012, 3 SOCBs (Bank of China, Industrial and Commercial Bank of China, and China Construction Bank) experience divestment from their foreign strategic investors. However, no CCBs and RCBs experiences divestment. Just 2 of 9 JOCBs (China Minsheng Bank and Shenzhen Development Bank) experience divestment from financial institutions. SOCBs more easily experience divestment and CCBs and RCBs do not easily experience divestment. From the divestment information and lock-up periods, we can get the following propositition:

Proposition 4: The longer periods of holding Chinese banks equity, foreign financial institutions have more incentive to improve the efficiency of Chinese banks, and more incentive to improve efficiency of CCBs and $R C B$ s than that of SOCBS.

Conflict of interests is likely to exist between Chinese banks and their foreign strategic investors. After China's entry into the WTO, China opened the banking market to foreign financial institutions on December 11, 2006 (Leigh \& Podpiera, 2006). This allows foreign financial institutions to establish incorporated banks in China, 
which can provide RMB-denominated services to local Chinese customers without geographical restrictions (CBRC, "Report on the Opening-up of the Chinese Banking Sector," January 25, 2007). This fact suggests that foreign financial institutions could establish their own banks in China instead of helping Chinese banks in strategic investments. For example, the Bank of China announced an exclusive partnership with RBS PLC's private-banking arm in 2007. However, it finally started only its own proprietary wealth-management business. Das and Teng (2000) also suggest that both cooperation and competition exist in foreign strategic investments, which generate instability of the investment.

The larger of the market share of Chinese banks, the bigger of the interest conflict between Chinese banks and foreign investors. As we all know, the market share of SOCBs is the biggest in China, and it has large business in both developed and developing cities in China. JOCBs also have big market share in developed cities in China. However, the major business of foreign financial institutions is located in developed big cities in China. Therefore, the direct competition between foreign financial institutions and SOCBs and JOCBs is very severe. The major business of CCBs and RCBs is located in certain cities and rurual areas, so the direct competition between foreign financial institutions and CCBs and RCBs is not so severe.

Proposition 5: The interest conflict between SOCBs and their foreign investors is larger than that between $C C B s / R C B s$ and their foreign investors.

\section{Conclusions and Discussion}

Foreign financial institutions' strategic investment in China's banking sector is to acquire certain equity stake of Chinese banks and provide business assistance and cooperation to them, it is one of the important foreign bank entry modes in China. This paper explores the impacting mechanism of foreign strategic investment on efficiency of Chinese banks. Foreign strategic investment has several characterisitics: foreign equity ownership should be less than $20 \%$ for one strategic investor; foreign financial institutions could send foreign directors to Chinese board; they must provide business cooperation with Chinese banks; their equity share must be locked up at least in 3 years.

Through analyzing the characteristics of foreign strategic investment and employing the equity incentive theory, corporate governance, technology transfer, and interest conflict, we give 5 propositions. Foreign financial institutions have larger equity stakes in CCBs, RCBs, and most JOCBs than that of SOCBs, so they would like to have more incentive to improve the efficiency of these small Chinese banks; foreign directors also have more incentive to improve the corporate governance of $\mathrm{CCBs}$, RCBs, and most JOCBs; foreign financial institutions would likely to transfer more technology to CCBs, RCBs and most JOCBs than that to SOCBs. The longer periods of holding Chinese banks equity, foreign financial institutions have more incentive to improve the efficiency of Chinese banks, and more incentive to improve efficiency of CCBs and RCBs than that of SOCBs. In addition, the interest conflict between SOCBs and their foreign investors is larger than that between $\mathrm{CCBs} / \mathrm{RCBs}$ and their foreign investors.

This paper just provides several propoisititions about the impacting mechanism of foreign strategic investment without empirically examination, so we need to collect more data to examine these propositions in the future works. Two potential methods should be used simultaneously. One method is to use the financial data and ownership information to examine the total impact of foreign strategic investment on efficiency of Chinese banks. The other method is to conduct interviews or questionnaires to understand the specific impact of foreign financial institutions' business cooperation on efficiency of Chinese banks.

\section{Acknowledgments}

Thispaper has been financially supported by National Natural Science Foundation of China (71363016 and 71263016), Jiangxi Province Social Science Twelve Five Project (13YJ09), China Postdoctoral Science Foundation (2014M551850), and Jiangxi Postdoctoral Science Foundation (2014KY57). Yuhua Li is the researcher of Jiahede-Jiangxi University of Finance and Economics Postdoctoral Innovation Practical Base.

\section{References}

Berger, A. N., Hasan, I., \& Zhou, M. (2009). Bank ownership and efficiency in China: What will happen in the world's largest nation? Journal of Banking and Finance, 33(1), 113-130. http://dx.doi.org/10.1016/j.jbankfin.2007.05.016

Bonin, J. P., \& Huang, Y. (2002). Foreign entry into Chinese banking: does WTO membership threaten domestic banks? The World Economy, 25(8), 1077-1093. http://dx.doi.org/10.1111/1467-9701.00482

Das, T. K., \& Teng, B. S. (2000). Instabilities of strategic alliances: An internal tensions perspective. 
Organization Science, 11(1), 77-101. http://dx.doi.org/10.1287/orsc.11.1.77.12570

García-Herrero, A., \& Santabárbara, D. (2008). Does the Chinese banking system benefit from foreign investors. BOFIT Discussion Papers, 11.

García-Herrero, A., Gavilá, S., \& D Santabárbara, D. (2009). What explains the low profitability of Chinese banks? Journal of Banking and Finance, 33(11), 2080-2092. http://dx.doi.org/10.1016/j.jbankfin.2009.05.005

Goldberg, L. S. (2007). Financial sector FDI and host countries: New and old lessons. Federal Reserve Bank of New York Staff Reports, No. 183 (April).

Hawes, C., \& Chiu, T. (2006). Foreign strategic investors in the Chinese banking market: Cultural shift or business as usual? Banking and Finance Law Review, 22(2), 203-237.

Hope, N., \& Hu, F. (2006). Reforming China's banking system: How much can foreign strategic investment help? In J. Aziz, S. Dunaway, \& E. Prasad (Eds.), China and India: learning from each other: reforms and policies for sustained growth (pp. 33-83). Washington, D. C.: IMF Multimedia Services Division.

Laurenceson, J., \& Qin, F. (2008). Has minority foreign investment in China's banks improved their cost efficiency? China \& World Economy, 16(3), 57-74. http://dx.doi.org/10.1111/j.1749-124X.2008.00114.x

Leigh, L., \& Podpiera, R. (2006). The rise of foreign investment in China's banks: Taking stock. IMF Working Paper, WP/06/292. http://dx.doi.org/10.5089/9781451865523.001

Li, Y. (2013). Motivation of foreign strategic investment in China's banking sector. Journal of International Management Studies, 8(1), 207-219.

Li, Y. (2014). International Strategic Alliance and Its Performance in China: The Resource-Based View, International Journal of Business and Management, 9(11). http://dx.doi.org/10.5539/ijbm.v9n11p170

Li, Y., \& Uchida, K. (2011). Divestment of foreign strategic investment in China's banking sector: Causes and consequences. In N. Boubakri, \& J. C. Cosset (Eds.), Institutional Investors in Global Capital Markets (pp. 83-110). Emerald Group Publishing Limited. http://dx.doi.org/10.1108/S1569-3767(2011)0000012006

Li, Y., \& Yue, Q. (2014). Determinants of foreign entry mode choice in China's banking sector. International Journal of $u$ - and e - Service, Science and Technology, 7(6).

Montgomery, H. (2003). The role of foreign banks in post-crisis Asia: The importance of method of entry. ADB Institute research paper.

Shen, C., Lu, C., \& Wu, M. (2009). Impact of foreign bank entry on the performance of Chinese banks. China \& World Economy, 17(3), 102-121. http://dx.doi.org/10.1111/j.1749-124X.2009.01153.x

Tan, M. N. T. (2009). Foreign investments in China's local banking sector- the Australian experience. China Economic Journal, 2(2), 209-217. http://dx.doi.org/10.1080/17538960903083525

Yuan, Y., \& Gunji, H. (2009). The impact of foreign capital on the Chinese banking market. China Economic Journal, 2(3), 285-296. http://dx.doi.org/10.1080/17538960903529519

Zhu, L. (2007). Impact of foreign entry on banks in emerging markets: The role of the pre-existing competitive environment. The George Washington University Ph.D dissertation.

Zhu, Y., Zeng, Y., Li, P., \& He, J. (2008). Chinese banks attract overseas strategic investors: Background, arguments and comments. Management World, (1), 22-37.

\section{Copyrights}

Copyright for this article is retained by the author(s), with first publication rights granted to the journal.

This is an open-access article distributed under the terms and conditions of the Creative Commons Attribution license (http://creativecommons.org/licenses/by/3.0/). 